\title{
PREDIGTION OF BREAKAGE DURING ROLLER MILLING OF MIXTURES OF WHEAT KERNELS, BASED ON SINGLE KERNEL MEASUREMENTS
}

\author{
IDA IDAYU MUHAMAD ${ }^{1 *}$, GHAOYING FANG² \& GRANT M. \\ CAMPBELL ${ }^{3}$
}

\begin{abstract}
Wheat flour milling involves repeated breakage (by roller milling) and separation (by sifting) of flour particles to give efficient recovery of fine flour relatively free from bran contamination. A starting point for modelling the behaviour of mixtures of wheat kernels is to be able to measure the variation in kernel properties within the mixture. The Perten Single Kernel Characterisation System (SKCS) gives the distributions of kernel mass, moisture content, diameter and hardness within a mixture, from 300 kernels within 5 minutes. A challenge remains to relate these measured distributions to predictions of milling performance. To this end, a breakage function in terms of these measured parameters for individual kernels has been constructed, and integrated over the distribution of kernel properties using the breakage equation. These models allow prediction of the output particle size distribution delivered by First Break roller milling of kernels varying in size, hardness and variety, based entirely on SKCS characteristics. Predictions have been developed for both sharp-to-sharp and dull-to-dull roll dispositions, and show encouraging agreement with independent data.
\end{abstract}

Keywords: Milling behaviour, particle size distribution, breakage, single kernel testing, wheat

\begin{abstract}
Abstrak Pengilangan tepung gandum melibatkan pengisaran bijirin secara berulang-kali (menggunakan roller mill) dan pemisahan (secara pengayakan) bagi perolehan semula hasilan tepung yang berkesan yang secara bandingannya bersih dari pencemaran bran. Satu permulaan bagi membina model perlakuan terhadap campuran bijirin gandum ialah keupayaan bagi menentu-ukur kelainan ciri-ciri yang wujud dalam campuran tersebut. Alatan Perten Single Kernel Characterisation System (SKCS) dapat memberikan taburan kuantitatif bagi jisim, kandungan lembapan, garis pusat dan nilai kekerasan bagi campuran bijirin tersebut, berdasarkan pengukuran 300 kernel dalam masa 5 minit. Cabarannya ialah menghubungkaitkan taburan yang telah ditentukur kepada ramalan keupayaan pengilangan. Pada tahap ini, satu bentuk kefungsian pengisaran (breakage function) dalam konteks parameter tentu-ukuran bagi setiap kernel bijirin telah diterbitkan, dan diintegrasi kepada taburan sifat kernel menggunakan persamaan proses pengisaran (breakage equation). Dengan menggunakan model tersebut, satu jangkaan boleh dilakukan ke atas taburan saiz partikel hasil keluaran pengisaran siri pertama atau First Break roller milling bagi kernel bijirin yang berbeza saiz, kekerasan dan kelainannya, berdasarkan hanya pada ciri-ciri taburan yang diberikan oleh SKCS. Model tersebut telah diuji ke atas hasil keluaran
\end{abstract}

Faculty of Chemical \& Natural Resources Engineering, Universiti Teknologi Malaysia, 81300 UTM Skudai, Johor, Malaysia

2\&3 Satake Centre for Grain Process Engineering, School of Chemical Engineering and Analytical Science, The University of Manchester, UK

* Corresponding author: Tel +607-5535541, Fax. +607-5581463, Email: idayu@fkkksa.utm.my 
pengisaran pada disposisi (roll disposition) pengisaran sharp-to-sharp dan dull-to-dull, dan didapati menunjukkan keseragaman dengan data bebas (independent data).

Kata kunci: Tingkah laku pengisaran, taburan saiz partikel, pemecahan, pengujian satu-kernel, bijirin

\subsection{INTRODUGTION}

Wheat kernels are initially broken into a wide range of particle sizes during First Break roller milling. These particles are separated by size using plansifting into several fractions, which are sent to different parts of the mill for repeated grinding and sifting operations to give efficient recovery of floury endosperm material, relatively free of bran contamination. The wheat entering the First Break rollers contains kernels varying in variety and geographical origin, and hence in size, hardness, protein content, etc. Even within a single variety grown in the same field, or within a single spike from the same wheat plant, wheat kernels vary in size and other physico-chemical characteristics $[1,2]$ and in functionality [3, 4]. Millers therefore need to be able to predict reliably of a heterogeneous mixture of wheat kernels with widely varying properties that will mill. The particle size distribution from First Break determines mills flow and balances throughout the rest of the mill; keeping the particle size distribution at this point constant, in the face of a varying feedstock of wheat, would greatly simplify the rest of the milling process.

The first step towards achieving this understanding of the behaviour of wheat mixtures is to be able to measure the variation in kernel characteristics within a batch of wheat. To this end, single kernel testing has become popular in recent years, culminating thus far in the introduction of the Perten Single Kernel Characterization System (SKCS), developed by the US Department of Agriculture [4-8]. The SKCS separates individual kernels from a sample, weights each kernel and then crushes each between a rotor and a crescent, while measuring the forcedeformation profile during crushing, along with the electrical conductivity of the grain. From the fundamental measurement, the SKCS calculates the mass, moisture content, diameter and hardness of each kernel, reports the distributions of these four parameters, along with the mean and standard deviation. The SKC.S is thus useful to millers as a quality control instrument at wheat intake. However, the information it delivers is potentially much more useful than merely indicating acceptance or rejection of wheat deliveries $[9,10]$. The difficulty is in interpreting distributions of size, hardness, etc. in terms of milling behaviour. Milling experience is primarily with bulk average measurements, but conceivably two wheat mixtures (grists) could have, for example, different kernel shapes but the same average hardness, however extremely different hardness profiles and hence milling behaviour [11].

The objective of the current work is to establish that the particle size distribution 
resulting from First Break milling of mixtures of wheat kernels could be predicted directly from SKCS characteristics. This work is part of a larger programme aimed at modelling and optimising the flour milling process.

\subsection{THEORY}

Previous work has introduced the breakage equation for roller milling and established the form of the breakage function in terms of kernel size, roll gap, moisture content and roll disposition [12-16]. The breakage equation is based on the fact that individual wheat kernels break independently during First Break milling, each according to its own physico-chemical characteristics. In the current work, kernel hardness was introduced into the breakage function. For reasons of practicality, the effect of moisture was excluded from the current work and all wheat samples conditioned to $16 \%$ moisture; in practice millers do not condition wheat's to widely varying moisture contents. The breakage equation in terms of kernel size, $\mathrm{D}$, and hardness, $\mathrm{H}$, is then

$$
P(x)=\int_{H=0}^{H=\infty} \int_{D=0}^{D=\infty} B(x, D, H) \rho_{D}(D) \rho_{H}(H) d D d H
$$

where $x$ is particle size in the outlet stream from First Break milling. $P_{2}(x)$ is the proportion of material in the outlet stream that is smaller than $x, B(x, D, H)$ is the breakage function, and $\rho_{D}(D)$ and $\rho_{H}(H)$ are the distributions of kernel size and hardness in the feed, respectively. $\rho_{D}(D)$ and $\rho_{H}(H)$ are measured by the SKCS; knowing the breakage function, the cumulative particle size distribution of the outlet from First Break can be predicted from the SKCS data by numerical integration of Equation (1).

\subsection{MATERIALS AND METHODS}

Table 1 shows the average physical properties for nineteen samples of wheat used in this study as measured by the Single Kernel Characterization System (Model 4100, Perten Instruments AB, Sweden) shown in Figure 1.

Before milling, 100 grams of each dry wheat sample was conditioned overnight to reach 16\% (optimum) moisture content, wet basis; this toughens the bran and germ and softens the endosperm, making the separation of endosperm from germ and bran easier. Then, the moist wheat was allowed to temper for at least 16 hours to give an even distribution of moisture. 
Table 1 The SKCS properties of nineteen varieties of wheat used in the study

\begin{tabular}{ccccc}
\hline $\begin{array}{c}\text { Wheat } \\
\text { variety }\end{array}$ & $\begin{array}{c}\text { Weight } \\
(\mathbf{m g})\end{array}$ & $\begin{array}{c}\text { Diameter } \\
(\mathbf{m m})\end{array}$ & $\begin{array}{c}\text { Hardness } \\
\text { index }\end{array}$ & $\begin{array}{c}\text { Moisture } \\
\text { content } \mathbf{( \% )}\end{array}$ \\
\hline Consort & 48.35 & 3.01 & 11.2 & 15.80 \\
Claire & 40.80 & 2.66 & 24.6 & 16.20 \\
Riband & 51.36 & 3.11 & 27.6 & 15.87 \\
Drake & 46.36 & 2.83 & 29.2 & 15.72 \\
Crofter & 51.06 & 2.98 & 42 & 15.89 \\
Soissons & 44.12 & 2.91 & 52.2 & 15.94 \\
Raleigh & 48.57 & 2.99 & 58.5 & 15.65 \\
Charger & 45.90 & 2.89 & 59.3 & 15.66 \\
Abbot & 45.32 & 2.95 & 61.1 & 15.65 \\
Buster & 52.01 & 3.33 & 62.7 & 15.65 \\
Avalon & 53.51 & 3.05 & 62.8 & 15.86 \\
Malacca6 & 44.02 & 2.93 & 63.2 & 16.17 \\
Hereward & 43.54 & 2.92 & 65.3 & 15.56 \\
Rialto & 50.58 & 3.08 & 65.7 & 15.82 \\
Brigadier & 51.03 & 3.02 & 67.1 & 15.51 \\
CWRS & 31.11 & 2.39 & 71.5 & 15.91 \\
Mercia & 44.28 & 2.90 & 73.6 & 15.54 \\
Cadenza & 56.32 & 3.35 & 76.9 & 15.80 \\
Spanish & 45.19 & 2.81 & 80.4 & 16.72 \\
\hline & & & &
\end{tabular}

Conditioned samples were milled on the Satake STR-100 test roller mill (Satake Corporation, Japan) at roll gaps $0.3-0.8 \mathrm{~mm}$ under both sharp-to-sharp (S-S) and dull-to-dull (D-D) roll dispositions. During milling, the breakage of wheat kernels during first break roller milling depends on many factors, including the disposition of the fluted rolls. Dull-to-dull gives slippage between the flutes and the kernel, and thus imparts less shear strain than sharp-to-sharp (see Figures 2 and 3).

The resulting particle size distributions were measured on a Simon plansifter using $200 \mathrm{~mm}$ diameter wire mesh sieves of aperture size: 2000, 1700, 1400, 1180, 850,500 and $212 \mathrm{um}$, along with a bottom pan. From these, the breakage functions incorporating kernel hardness, diameter and roll gap were constructed for each milling disposition. A further four varieties, plus two 50:50 mixtures of varieties, were milled to obtain independent data with which to validate the predictions. SKCS characteristics for all 23 wheat varieties were measured using the SKCS 4100 (Perten Instruments AB, Sweden). 


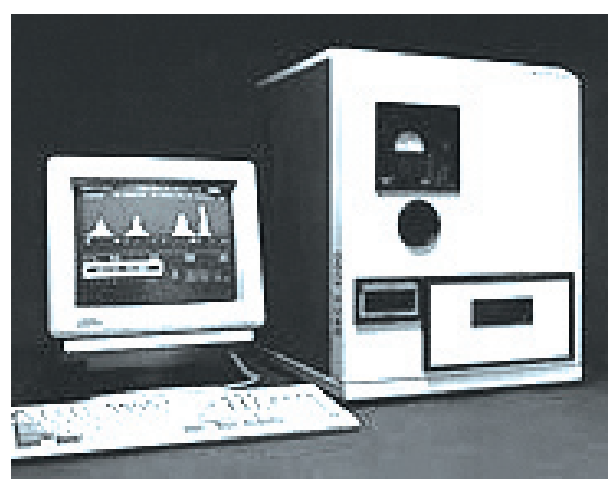

Figure 1 Single Kernel Characterization System 4100 (Perten Instruments, 1995)

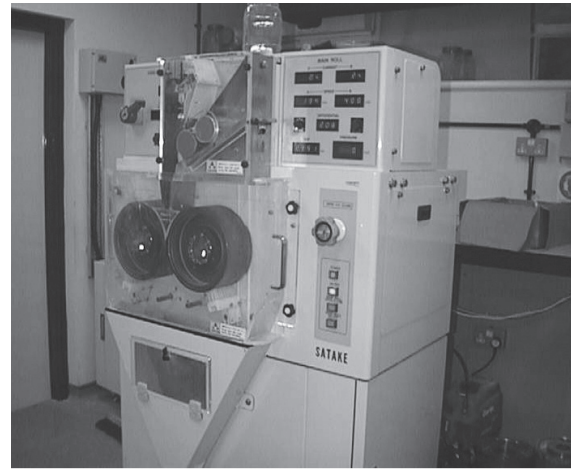

Figure 2 Satake STR-100AU test roller mill

Figure 3 Roller mill at disposition sharp-to-sharp and dull to dull

\subsection{RESULTS AND DISGUSSION}

Figures 4 - 6 show the percentage smaller than $x$ for various values of outlet particle size, at a roll gap of $0.3 \mathrm{~mm}, 0.6 \mathrm{~mm}$ and $0.8 \mathrm{~mm}$, for both D-D and S-S roll dispositions, for the 19 wheat varieties. The fitted breakage function is also shown. Clearly, as hardness increases, the proportion of flour stocks smaller than $212 \mu \mathrm{m}$ decreases under both dispositions. The proportion of material larger than 2000 $\mu \mathrm{m}$ also decreases, while the proportion of mid-range particles increases with hardness. The effect of hardness is greater under D-D milling, which produces a larger proportion of very large and very small particles, with fewer in the mid-size range, compared with S-S. These results agree with previous findings [14]. Similar results were obtained at other roll gaps, with larger roll gaps producing larger output particle sizes. The results from different wheat varieties show consistent trends, indicating that the SKCS hardness measurement is meaningful in terms of actual breakage during roller milling, although some samples depart significantly from the general trend. 


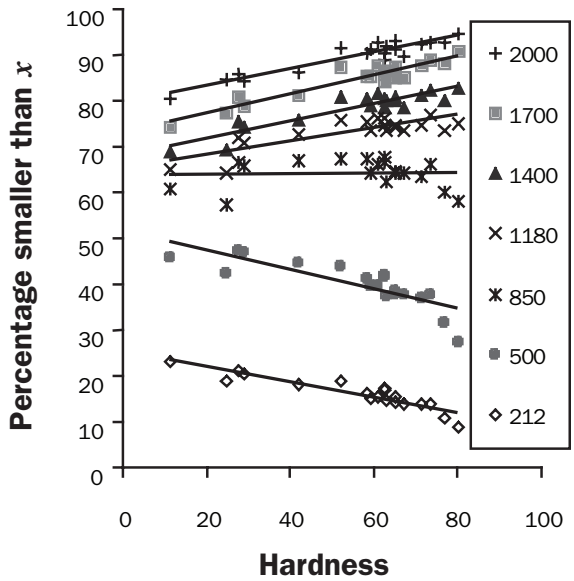

(a)

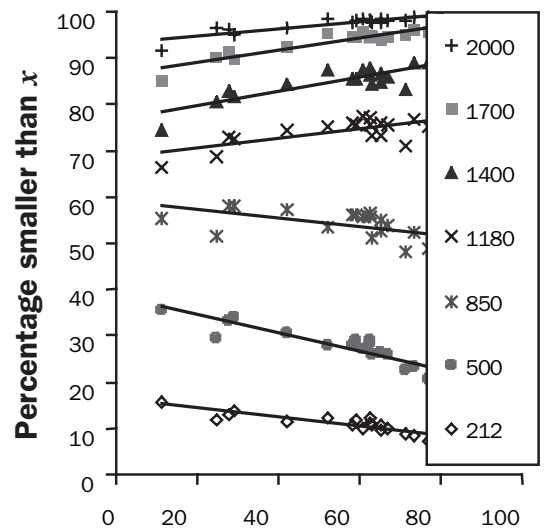

Hardness

(b)

Figure 4 Percentage smaller than $x$ versus hardness under (a) dull-to-dull; and (b) sharp-tosharp roll dispositions at roll gap $0.3 \mathrm{~mm}$

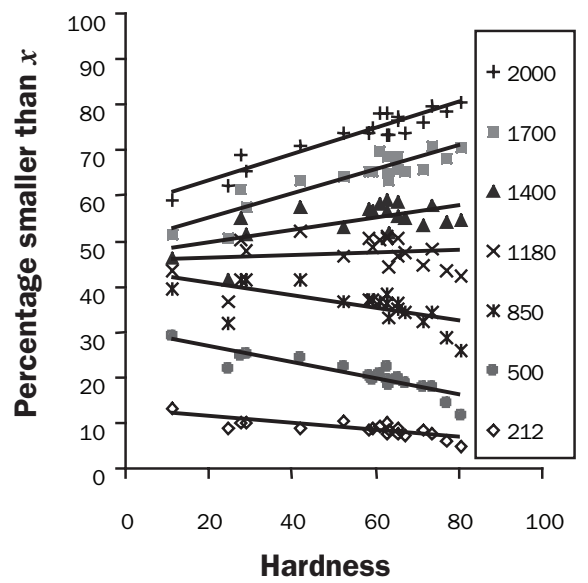

(a)

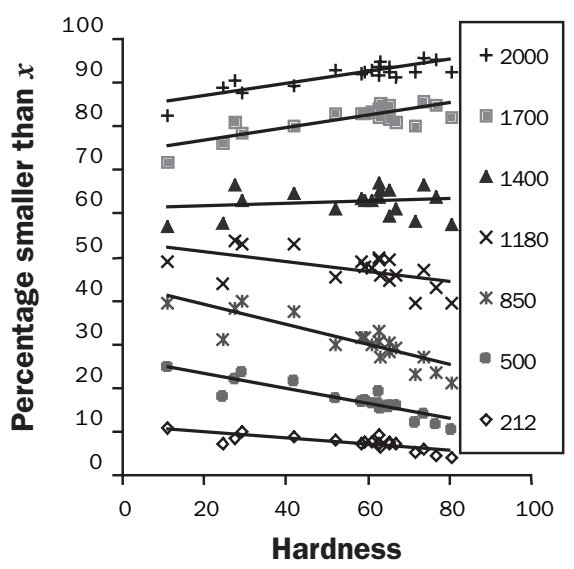

(b)

Figure 5 Percentage smaller than $x$ versus hardness under (a) dull-to-dull; and (b) sharp-tosharp roll dispositions at roll gap $0.6 \mathrm{~mm}$ 


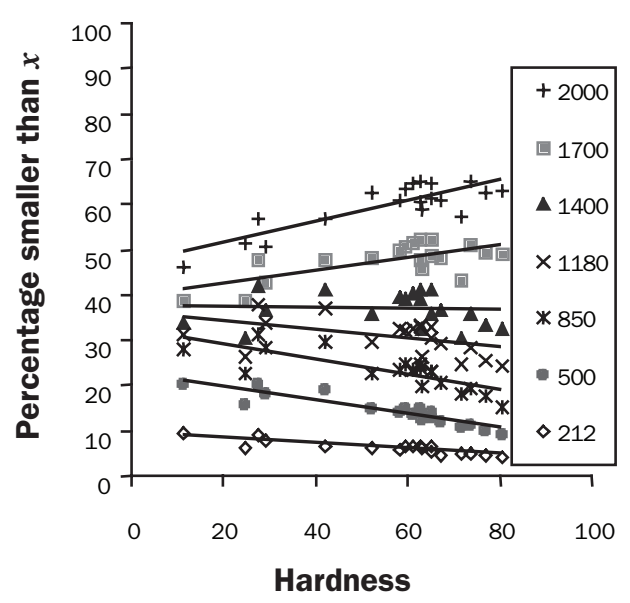

(a)

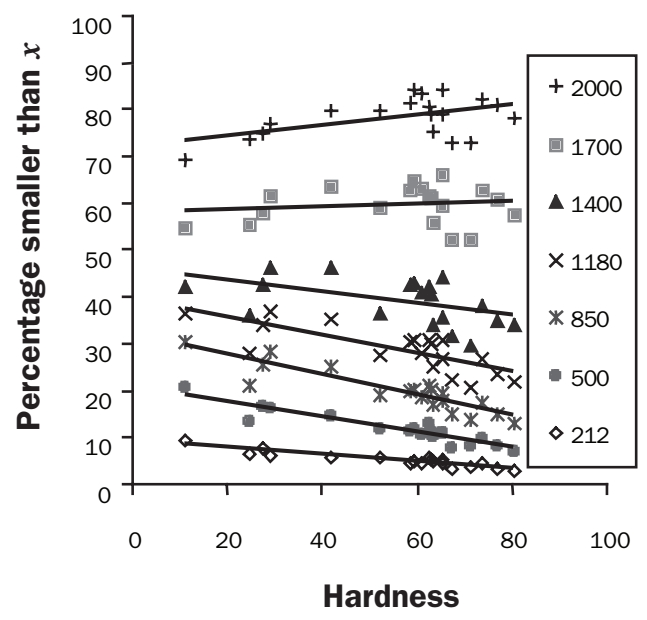

(b)

Figure 6 Percentage smaller than $x$ versus hardness under (a) dull-to-dull; and (b) sharp-tosharp roll dispositions at roll gap $0.8 \mathrm{~mm}$

Figure 7 shows the predicted and experimental cumulative particle size distributions for Consort (a soft wheat, SKCS hardness $=23.7$ ) and Spark (a hard wheat, SKCS hardness $=74.4)$ at three roll gaps under D-D milling. The agreement between the predictions and the independently-derived experimental data is excellent. Similar agreements were obtained for a 50:50 mixture of these two wheats.

A similarly good result (result not shown) was obtained for Malacca (SKC.S hardness $=61.5$ ) under both the S-S and D-D milling, but Soissons (SKCS hardness $=54.4$ ) and Malacca50/Soissons50 did not give quite such good agreement.

Clearly, the inclusion of hardness in the breakage function has gone a long way towards making the breakage function more universal; however, there are still some wheat varieties for which good predictions are not achieved. This may be due to additional factors such as kernel shape. Work is ongoing to include the other SKCS data to produce a more comprehensive breakage function, and to identify whether other single kernel parameters such as density are needed to allow truly universal predictions. 


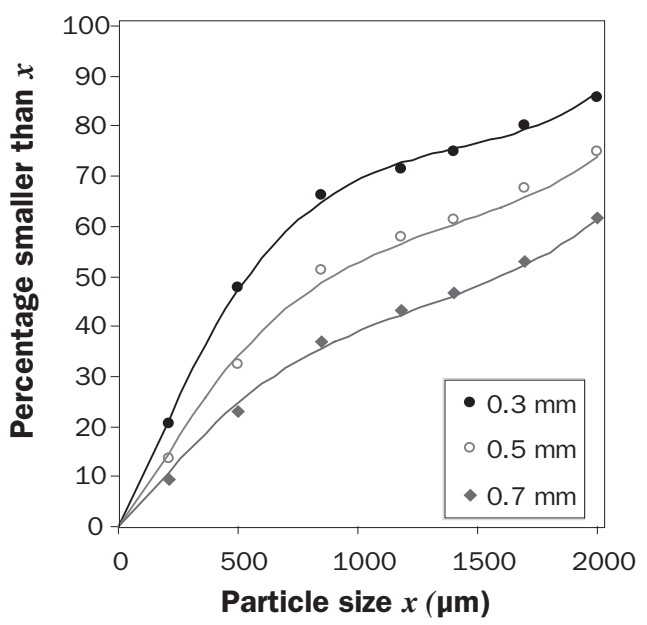

(a)

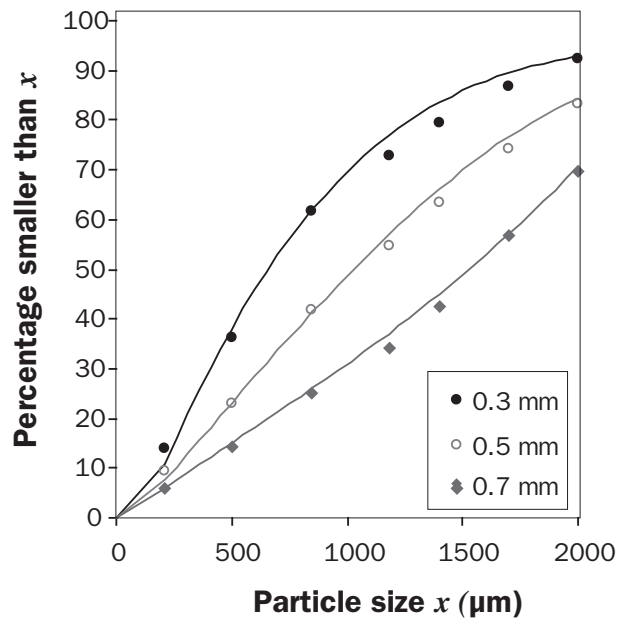

(b)

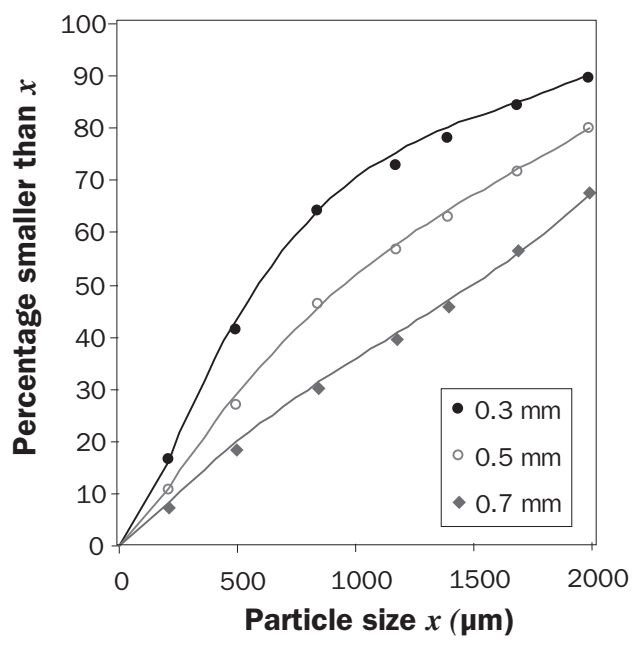

Figure 7 Predicted (lines) and experimental (symbols) cumulative particle size distributions for (a) Consort; (b) Spark and (c) Consort50/Spark50 wheats milled at different roll gaps under a D-D disposition

\subsection{GONGLUSIONS}

Prediction of the particle size distribution resulting from First Break roller milling of unknown wheatsamples or mixtures under S-S or D-D milling has been demonstrated, based solely on integration of SKCS size and hardness distribution data using the breakage equation for roller milling. Additional single kernel information such as mass, density, kernel shape and moisture content, and their effects on the particle 
size distribution from First Break milling of wheat are needed to be incorporated to allow universally applicable breakage functions to be established.

\section{ACKNOWLEDGEMENTS}

This work was funded by the Engineering and Physical Sciences Research Council (EPSRC, grant no. GR/M49939). The authors are grateful to Universiti Teknologi Malaysia and the Satake Corporation of Japan for supporting the research.

\section{REFERENGES}

[1] Evers, A. D. 1996. New Opportunities in Wheat Grading. The Nordic Cereal Industry Towards Year 2000. Proceedings of $26^{\text {th }}$ Nordic Cereal Congress. 61-67.

[2] Doehlert, D. C., M. S. McMullen, and N. R. Riveland. 2002. Sources of Variation in Oat Kernel Size. Cereal Chemistry. 79: 528-534.

[3] Sutton, K. H., R. L. Hay, and C. H. Mouat. 1992. The Effect of Kernel Weight on the Assessment of Baking Performance of Wheat's by RP-HPLC of Glutenin Subunits from Single Grains. 7. Cereal Science. 15: 253-265.

[4] Ohm, J. B., O. K. Chung, and C. W. Deyoe. 1998. Single-Kernel Characteristics of Hard Winter Wheats in Relation to Milling and Baking Quality. Cereal Chemistry. 75(1): 156-161.

[5] Martin, C. R., R. Rousser, and D. L. Brabec. 1993. Development of a Single-kernel Wheat Characterization System. Trans. ASAE. 36: 1399-1404.

[6] Sissons, M. J., B. G. Osborne, R. A. Hare, S. A. Sissons, and R. Jackson. 2000. Application of the Singlekernel Characterization System to Durum Wheat Testing and Quality Prediction. Cereal Chemistry. 77(1): 4-10.

[7] Osborne, B. G. 2001. Wheat Flour Milling, Part 2. In Cereals and Cereal Products: Chemistry and Technology. D. A. V. Dendy and B. J. Dobraszczyk (Eds.). Maryland, USA: Aspen Publishers Inc. 172-181.

[8] Osborne, B. G., R. Jackson, and S. R. Delwiche. 2001. Rapid Prediction of Wheat Endosperm Compressive Strength Properties Using the Single-Kernel Characterisation System. Cereal Chemistry. 78(2): 142-143.

[9] Muhamad, I. I. and G. M. Campbell. 2004. Effects of Kernel Hardness and Moisture Content on Wheat Breakage in the Single Kernel Characterisation System. Innovative Food Sci Emerging Technol. 5: 119-125.

[10] Muhamad, I. I., C. Y. Fang, and G. M. Campbell. 2006. Comparison of Grain Particle Size Distribution in the Single Kernel Characterisation System and During First Break Roller Milling. Jurnal Teknologi. 44(A): 41-52.

[11] Campbell, G. M. G. Y. Fang, and I. I. Muhamad. 2007. On Predicting Roller Milling Performance VI. Effect of Kernel Hardness and Shape on the Particle Size Distribution from First Break Milling of Wheat. IChemE fournal: Food and Bioproduct. 85(1): 7-23.

[12] Campbell, G. M. and C. Webb. 2001. On Predicting Roller Milling Performance, Part I: The Breakage Equation. Powder Technology. 115(3): 234-242.

[13] Campbell, G. M., P. J. Bunn, C. Webb, and S. C. W. Hook. 2001. On Predicting Roller Milling Performance. Part II. The Breakage Function. Powder Technology. 115(3): 243-255.

[14] Fang, C. Y. and G. M. Campbell. 2002. Effect of Roll Fluting Disposition and Roll Gap on the Breakage of Wheat Kernels During First Break Roller Milling. Cereal Chemistry. 79(4): 518-522.

[15] Fang, G. Y. and G. M. Campbell. 2003a. On Predicting Roller Milling Performance. Part IV. Effect of Roll Disposition on the Particle Size Distribution from First Break Milling of Wheat. 7. Cereal Sci. 37: 21-29.

[16] Fang, C. Y. and G. M. Campbell. 2003b. On Predicting Roller Milling Performance. Part V. Effect of Moisture Content on the Particle Size Distribution from First Break Milling of Wheat. 7. Cereal Sci. 37: $31-41$. 